\title{
Film Dokumenter Menepis Julukan Negatif Joged Bumbung
}

\author{
Agus Ari Darma Premana ${ }^{1}$, I Gede Mahendra Darmawiguna ${ }^{2}$, Gede Aditra Pradnyana ${ }^{3}$ \\ Program Studi Pendidikan Teknik Informatika \\ Jurusan Teknik Informatika \\ Fakultas Teknik dan Kejuruan \\ Universitas Pendidikan Ganesha \\ Email : aridarmapremana@gmail.com ${ }^{1}$, mahendra.darmawiguna@undiksha.ac.id ${ }^{2}$, gede.aditra@undiksha.ac.id ${ }^{3}$
}

\begin{abstract}
Abstrak - Tari Joged Bumbung adalah salah satu tari bali yang bersifat balih-balihan atau hiburan. Tari Joged Bumbung sangat popular di kalangan masyarakat Bali sampai saat ini. Maraknya peredaran video "Joged Bumbung Porno" membuat kesenian ini dipandang negatif. Film dokumenter dapat menjadi media untuk memberikan informasi perkembangan tari joged bumbung dan juga melestarikannya serta menepis julukan negatif terhadap kesenian ini. Penelitian ini bertujuan untuk (1) mengetahui rancangan dan implementasi pembuatan Film Dokumenter Menepis Julukan Negatif Joged Bumbung (2) mengetahui respon masyarakat mengenai Film Dokumenter Menepis Julukan Negatif Joged Bumbung. Jenis penelitian yang digunakan dalam penelitian ini adalah penelitian dan pengembangan dengan model cyclic strategy dimana model ini memiliki beberapa tahapan yang harus dilakukan dan jika ada tahapan yang tidak sesuai harus melalukan pengulangan yang biasa disebut loop. Film dokumenter ini diimplementasikan dengan menggunakan aplikasi Adobe Premier Pro CS6 dalam proses editing serta Adobe Photoshop CS6 untuk pembuatan desain keperluan film dokumenter. Hasil dari penelitian ini adalah media film dokumenter yang menjalaskan perkembangan tari joged bumbung dan untuk respon dari masyarakat terhadapat media ini dikatagorikan baik dengan hasil respon sebesar 81,69\%.
\end{abstract}

Kata Kunci : Tari Joged Bumbung, Tari Bali, Film Dokumenter, Cyclic Strategy.

Abstract - Joged Bumbung dance is one of the Balinese dances which is "balih-balihan" dance or entertainment. Joged Bumbung dance is very popular for among Balinese people. The rise of the circulation of the "Joged Bumbung Porno" video made this art considered negative. Documentary films can be a medium to provide information on the development of "joged bumbung" dance and also preserve it and dismiss the negative considered. This study aims to (1) find out the design and implementation of the Joged Bumbung Documentary Films (2) to find out the public response to the Joged Bumbung Documentary Films. The type of research used in this study is research and development with a cyclic strategy model where this model has several steps that must be done and if there are stages that are not appropriate, it must do looping. This documentary is implemented using the Adobe Premier Pro CS6 application in the editing process as well as Adobe Photoshop CS6 for making documentary film design needs. The results of this study are documentary films that describe the development of joged bumbung dance and for the response to this media categorized "well" with $81.69 \%$ rates responses. Keywords: Joged Bumbung Dance, Balinese Dance, Film
Documentary, Cyclic Strategy

\section{PENDAHULUAN}

Pulau Bali adalah salah satu kepulauan di Negara Indonesia yang memiliki keindahan alam dan keunikan budayanya. Warisan budaya ini sangat beranekaragam salah satunya kesenian tari-tarian. Kesenian ini dibagi menjadi tiga kelompok, kesenian yang bersifat sakral dan disucikan (wali), kesenian yang bersifat sebagai pengiring upacara agama (bebali) dan kesenian yang bersifat sebagai tontonan dan hiburan semata (balih-balihan) (Bandem, 1996). Salah satu kesenian tersebut adalah pertunjukan tari-tarian Bali yang mampu menyedot antusias masyarakat untuk menyaksikannya. Dari kesenian tari-tarian inilah Bali bisa dikenal hingga kemancanegara dan menjadi warisan budaya bagi bangsa ini [2].

Sebagai warisan budaya yang sangat kental dengan unsur seni dan keagamaan, beberapa seni tari Bali dimasukkan ke dalam daftar Warisan Budaya Tak Benda. Sebelumnya lewat sidang ke-10 Komite Warisan Budaya Tak Benda UNESCO di Windhoek, Namibia, pada 2 Desember 2015 telah menetapkan untuk memasukkan tiga golongan tari tradisi Bali yang terdiri dari sembilan tari ke dalam daftar Warisan Budaya Tak Benda (Manggala, 2015). Kesembilan tari tersebut adalah tari Rejang, tari Sanghyang Dedari, dan tari Baris Upacara yang digolongkan sebagai tarian sakral (tari wali), tari Topeng Sidhakarya, drama tari Wayang Wong, drama tari Gambuh yang digolongkan sebagai tarian semi sakral (tari bebali) dan tari Legong Keraton, tari Joged Bumbung dan Barong Ket 


\section{ISSN \\ Kumpulan Artikel Mahasiswa Pendidikan Teknik Informatika}

"Kuntisraya" yang digolongkan sebagai tarian hiburan (tari balih-balihan). Menurut Prof. Dr. I Made Bandem, sembilan tari tersebut wajib masuk kurikulum terutama wajib untuk Institut Seni Indonesia Denpasar Jurusan Tari (Manggala, 2015) [5].

Salah satu tari balih-balihan yang tercatat di dalam daftar Warisan Budaya Tak Benda adalah tari joged bumbung. Tari joged bumbung adalah salah satu seni pertunjukan yang tumbuh di tengah-tengah masyarakat agraris. Tari joged bumbung adalah salah satu kesenian tari Bali yang sangat sederhana dan merakyat di Bali sebagai suatu hiburan di kalangan masyarakat Bali dari jaman dahulu hingga kini. Joged bumbung secara terminology terdiri dari kata joged yang secara lugas berarti gerak, dinamis dan menari. Bumbung adalah kata yang diambil dari bahasa daerah yang berarti bambu. Dalam konteks seni, joged bumbung merupakan bentuk kesenian yang memadukan antara seni tabuh dengan tari (Winyana, 2015) [9].

Kebebasan menciptakan inovasi baru joged bumbung ini mengakibatkan perkembangannya menjadi tidak terkontrol dan keluar dari pakemnya. Joged bumbung yang dulu memiliki makna sebagai tarian pergaulan dan merakyat, tetapi saat ini sudah dirusak oleh oknum-oknum yang tidak bertanggung jawab dan secara kasat mata terlihat sangat buruk. Muncullah joged bumbung sebagai sesuatu yang fenomenal. Tidak lagi dipandang sebagai tarian yang sederhana, tetapi sudah berubah menjadi joged porno nan erotis (BPNBBali, 2015) [3].

Menurut hasil penyebaran angket yang dilakukan mendapatkan hasil bahwa $80 \%$ menyatakan bahwa penari joged bumbung dengan gerakan yang mengandung unsur pornografi melakukan gerakan tari keseluruhan secara sadar. Kemudian $56 \%$ menyatakan bahwa video tari joged bumbung yang didapat dan ditonton lebih banyak mengandung unsur pornografi dalam gerakannya.

Berdasarkan permasalahan yang telah diuraikan di atas, maka penulis bermaksud mengembangkan penelitian yang berjudul "FILM DOKUMENTER MENEPIS JULUKAN NEGATIF JOGED BUMBUNG". Dimana pesan yang ingin disampaikan melalui film dokumenter ini adalah menunjukkan bahwa kesenian tari joged bumbung ini walaupun hanya sebagai tari balih-balihan atau hiburan semata namun harus tetap dalam kaidah tari Bali, sehingga pandangan negatif masyarakat tentang joged bumbung tidak lagi terjadi.

\section{KAJIAN PUSTAKA \& LANDASAN TEORI}

\section{A. Penelitin Terkait}

Adapun beberapa hasil penelitian yang terkait dengan penelitian film dokumenter ini, yaitu sebagai berikut :

1) Ciptadi dan Tumimomor (2013), dipaparkan mengenai "Perancangan Film Pasar Terapung Muara Kuin Di Banjarmasin Kalimantan Selatan", bahwa permasalahan dalam penelitian ini adalah masyarakat mulai meninggalkan pasar terapung Muara Kuin ini akibat perkembangan teknologi transportasi yang semakin maju di jaman ini. Metode yang digunakan dalam film ini yaitu cyclic strategy. Dari penelitian ini didapatkan hasil bahwa film dokumenter bisa menjadi sarana media informasi untuk melestarikan budaya yang ada di suatu daerah. Hasil dari penelitian ini adalah berupa video dokumeter yang bersikan informasi mengenai Pasar Terapung Muara Kuin, yang diharapkan dapat menghimbau masyarakat dalam menjaga dan melestarikan keberadaan Pasar Terapung Muara Kuin di jaman modern ini [4].

2) Penelitian oleh Narayana (2017) mengenai "Film Dokumenter Tok Lait Kancing : Sebuah Warisan Karakter Budaya Bangsa" memaparkan bahwa permasalahan yang diangkat adalah masih banyak masyarakat yang tidak mengetaui permainan tok lait kancing terutama siswa-siswi yang masih bersekolah. Metode yang digunakan dalam film ini yaitu cyclic strategy. Hasil yang didapat dari penelitian ini adalah sebuah film dokumenter yang bisa dijadikan sebagai media untuk sosialisasi permainan tok lait kancing pada siswa-siswa sekolah. Penelitian ini juga berhasil masuk kedalam katagori sangat baik dengan hasil uji alhi isi dan uji ahli media serta hasil uji responden juga mencapai $93,33 \%$ yang masuk kedalam katagori sangat baik [6].

3) Selain itu penelitian oleh Yudiana Sucitra (2017) yang berjudul "Pengembangan Film Dokumenter Tradisi Dewa Mesraman Di Pura Panti Timrah Klungkung" mengangkat permasalahan pada era globalisasi saat ini pencapaian spiritualisme masyarakat masih tergolong rendah, dimana masyarakat masih memiliki pandangan dan pengertian yang berbeda terhadap tradisi Dewa Mesraman. Tujuan yang ingin dicapai adalah memperkuat keinginan masyarakat untuk mempertahankan tradisi yang telah diwariskan serta meluruskan perbedaan persepsi masyarakat tentang Tradisi Dewa Mesraman. Metode yang digunakan dalam penelitian ini adalah cyclic strategic Hasil pengujian dari film dokumenter ini mendapat respon yang baik dengan tingkat pencapaian sebesar $96 \%$ sebagai sebuah film yang menarik dan dapat digunakan dalam pelestarian budaya Bali [10].

\section{B. Tari Bali}

Tari Bali adalah tarian yang berasal dari Bali. Tari Bali adalah salah satu kesenian dari Bali yang menyuguhkan sebuah pertunjukan melalui gerakan-gerakan dengan iringan musik gamelan Bali. Jenis tari Bali sangat beragam dan memiliki makna tersendiri dalam pementasannya serta dengan gerakangerakan yang berbeda sesuai dengan cerita yang dilakonkan. Keberadaan tari Bali memang sangat melekat dengan unsur religious dan sakral dalam agama Hindu. Sejalan dengan perkembangan jaman tarian Bali yang pada awalnya hanya dipertunjukkan di acara-acara tertentu, saat ini sering 


\section{ISSN \\ Kumpulan Artikel Mahasiswa Pendidikan Teknik Informatika}

dipentaskan untuk menjadi sebuah hiburan bagi para wisatawan namun tidak semua tarian Bali dikatagorikan sebagai sebuah hiburan (Bandem, 1996)[2].

\section{Tari Joged Bumbung}

Joged bumbung secara terminology kata terdiri dari joged yang secara lugas berarti gerak, dinamis, dan menari. Bumbung adalah kata yang diambil dari bahasa daerah yang berarti bambu. Dalam konteks seni, joged bumbung merupakan bentuk kesenian yang memadukan antara seni tabuh dengan tari. Perpaduan kedua unsur itu menghasilkan pertunjukan di mana permainan yang dikembangkan membolehkan penonton yang tertarik untuk turut menari disaat pementasan seni joged berlangsung (Winyana, 2015) [9].

Tari joged bumbung ini ditarikan oleh seorang wanita dengan iringan gamelan gegrantangan atau alat gamelan yang terbuat dari bambu. Pada awal tarian, penari akan menari sendiri sebagai sebuah pembukaan. Kemudian dipertengahan tarian, penari akan mengajak penonton lawan jenis untuk ikut menari bersama yang biasa disebut dengan ngibing. Pengibing biasanya dipilih secara acak dan pada saat akan menari bersama, pengibing diberikan sebuah selendang yang dililitkan di pinggang sebagai pertanda siap untuk ngibing. Setiap penari akan mengajak beberapa pengibing secara bergantian beberapa kali sampai batas waktu yang telah disepakati. Dalam sebuah pementasan, penari joged bumbung ditarikan oleh 2 hingga 4 orang penari secara bergantian. Pementasan Joged bumbung ini biasanya dilakukan pada malam hari. Gerakan-gerakan yang ditarikan oleh penari hanya sebatas goyangan pinggul dan gerakan tari pada umumnya yang lebih mudah untuk menarik perhatian pengibing. Seiring dengan adanya persaingan akibat sekaa joged bumbung semakin banyak, terjadilah berbagai inovasi yang dilakukan mulai dari gamelan yang digunakan, pakaian, hingga gerakan penari yang melenceng sehingga joged bumbung sebagai tari pergaulan mempunyai ciri khas yakni mengandung unsur sensualitas dan seksualitas namun tetap dianggap berada pada batas kewajaran (Atmadja, 2010) [1].

\section{Film Dokumenter}

Film dokumenter termasuk ke dalam bagian film nonnaratif (non cerita) dengan kata kunci pertama adalah fakta. Film dokumenter selain mengandung fakta juga mengandung subjektivitas pembuat. Subjektivitas diartikan sebagai sikap atau opini terhadap peristiwa. Jadi, ketika faktor manusia ikut berperan, persepsi tentang kenyataan akan sangat bergantung pada manusia pembuat film dokumenter itu (Sumarno, 1996).[8]

Film dokumenter tidak menciptakan suatu peristiwa atau kejadian namun merekan peristiwa yang sungguh-sungguh terjadi atau otentik, tidak seperti film fiksi, film dokumenter tidak memiliki plot namun memiliki struktur yang umunnya didasarkan oleh tema atau argumen dari sineasnya. Film dokumenter juga tidak memiliki tokoh protagonis dan antagonis, konflik, serta penyelesaian seperti halnya film fiksi.
Volume 8, Nomor 2, Tahun 2019

Struktur film dokumenter umunya sederhana dengan tujuan agar memudahkan penonton untuk memahami dan mempercayai fakta-fakta yang disajikan yang disajikan

E. Model Cyclic Strategy

Metode penelitian yang digunakan dalam film dokumenter menepis julukan negatif joged bumbung adalah model cyclic strategy. Medel cyclic strategy atau strategi berputar merupakan sebuah metode yang ada kalanya suatu tahap perlu diulang kembali sebelum tahap berikutnya dilanjutkan. Pengulangan tahap ini sering disebut dengan loop. Pengulangan tahap ini dimaksudkan untuk menampung umpan balik (feedback) sebelum tahap berikutnya dilanjutkan (Sarwono \& Lubis, 2007)[8].

Tahap - tahap yang ada pada model cyclic strategy dapat dilihat pada Gambar 1.

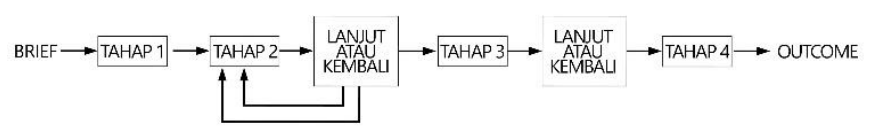

Gambar 1. Model Cyclic Strategy

\section{METODOLOGI PENELITIAN}

\section{A. Metode Penelitian}

Metode penelitian yang digunakan untuk film dokumenter Menepis Julukan Negatif Joged Bumbung adalah model cyclic strategy atau strategi berputar. Tahap-tahap dalam model cyclic strategy yang diimplementasikan ke dalam metodelogi penelitian dapat dilihat pada Gambar 2. (Pratista, 2008)[7]. 


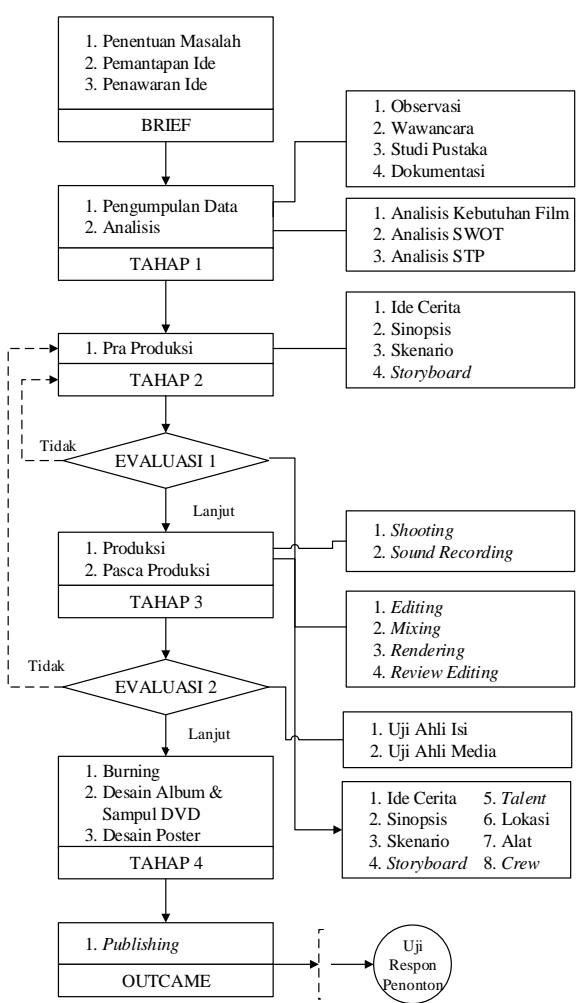

Gambar 2 Tahapan Model Cyclic Strategy

1) Brief (Penentuan masalah, pemantapan ide, penawaran ide)

Brief merupakan tahap awal dari perancangan Film Dokumenter Menepis Julukan Negatif Joged Bumbung. Pada tahapan ini terdapat tiga fase yaitu :

1. Penentuan masalah.

2. Pemantapan ide.

3. Penawaran ide.

2) Tahap 1 (Pengumpulan Data dan Analisis)

1) Pengumpulan Data

Teknik pengumpulan data tersebut dijabarkan sebagai berikut.:

a. Observasi dan Penyebaran Angket.

b. Wawancara.

c. Studi pustaka.

e. Dokumentasi.

2) Analisis

Setelah data terkumpul, maka dilakukan sebuah analisis guna mengetahui kelebihan, kekurangan maupun target audiens film dokumenter. Berikut merupakan analisis yang dibutuhkan dalam pebutan film dokumenter :
a. Analisa Talent
b. Analisa Lokasi
c. Analisa Alat

d. Analisa Crew

e. Analisa SWOT

f. Analisa STP.

3) Tahap 2 (Pra Produksi)

Pada tahap 2 terdapat fase pra produksi. Dimana fase pra produksi sangat menentukan dalam sukses atau tidaknya sebuah film. Informasi yang telah terkumpul pada fase pengumpulan data akan diolah di fase pra produksi. Pra produksi meliputi beberapa tahapan, yaitu perancangan ide cerita, sinopsis, dan storyboard.

\section{4) Evaluasi 1}

Setelah tahap 2 ini akan ada pengujian yang bertujuan mengecek kembali apakah semua bagian dalam tahap 1 dan tahap 2 telah benar-benar terlaksana. Jika ada yang belum terlaksana maka akan dilakukan looping / pengulangan dengan merevisi kembali rancangan film. Sedangkan jika semua telah terlaksana maka akan dilanjutkan ke tahap berikutnya. Pengujian di sini dilakukan oleh peneliti itu sendiri.

5) Tahap 3 (Produksi dan Pasca Produksi)

Adapun fase-fase yang terdapat pada Tahap 3 yaitu :

1. Produksi

Pada fase ini dibagi menjadi dua, antara lain:
a. Shooting
b. Sound Recording

2. Pasca Produksi

Dalam tahapan pasca produksi dilakukan beberapa hal, antara lain:
a. Editing
b. Mixing
c. Rendering
d. Review Editing

6) Evaluasi 2 (Evaluasi Ahli)

Setelah Tahap 3 selesai, maka film dokumenter tersebut dievaluasi oleh para ahli di Tahap Evaluasi 2. Terdapat dua pengujian, yaitu uji ahli isi dan uji ahli media.

7) Tahap 4

Tahap 4 merupakan tahapan akhir sebelum film ini disebarluaskan. Pada tahap 4 ini terdapat fase mastering. Mastering merupakan proses dimana file yang telah di-render dipindahkan kedalam media DVD atau media lainya. Pada tahap ini juga dilakukan perancangan desain cover. 


\section{ISSN \\ Kumpulan Artikel Mahasiswa Pendidikan Teknik Informatika}

\section{8) Outcome}

Outcome merupakan tahapan terakhir dari pembuatan film dokumenter ini. Tahap terakhir yaitu publikasi. Produk akhir film yang telah dikemas dalam bentuk DVD siap dipublikasikan, target publikasi disesuaikan dengan target penonton. Pada tahap ini juga dilakukan promosi yaitu dengan cara membuat poster dan trailer film. Tahap ini juga dilakukan uji respon dengan tujuan untuk mengetahui respon penonton tentang film dokumenter.

9) Uji Respon Penonton

Uji respon penonton dilakukan utuk mengetahui tanggapan penonton terhadat film ini. Uji respon dilakukan dengan penyebaran angket kepada masyarakat.

\section{HASIL \& PEMBAHASAN}

\section{A. HASIL}

1. Hasil Tahap Brief

Brief merupakan tahap persiapan awal untul melakukan penelitian ini. Di mana tahap awal dari penelitian ini adalah penentuan masalah, pemantapan ide dan juga penawaran ide kepada pihak jurusan dan disetujui pada tanggal 4 Maret 2016.

\section{Hasil Tahap 1 (Pengumpulan data \& Analisis)}

Pada tahap 1 ini terdapat beberapa fase yaitu pengumpulan data dan analisis. Di mana hasil dari fase tersebut dapat dijabarkan sebagai berikut.

1) Pengumpulan data

Dalam pembuatan film dokumenter ini menggunakan beberapa teknik pengumpulan data. Teknik pengumpulan data dijabarkan sebagai berikut.

a. Observasi dan penyebaran angket.

Pengumpulan data secara observasi dilakukan dengan cara menonton pertunjukan tari joged bumbung melalui video serta melihat proses persiapan sebelum pertunjukan berlangsung dan mengumpulkan informasi melalui media cetak maupun elektronik seperti youtube ataupun artikel berita online dan juga penyebaran angket.

\section{b. Wawancara}

Melakukan wawancara dengan narasumber dengan cara mengajukan beberapa pertanyaan mengenai keberadaan Sekaa Joged Bumbung di Buleleng. Narasumber yang diwawancarai diantaranya adalah ketua Sekaa Joged Bumbung Dwi Tunggal yang berlokasi di desa Menasa, Sinabun Buleleng, ketua Sekaa Wahyu Ulangun yang berada desa Nagasepaha, Sukasada Buleleng.
Volume 8, Nomor 2, Tahun 2019

c. Studi Pustaka

Studi pustaka dilakukan untuk mengumpulkan data dari sumber tertulis maupun tidak tertulis seperti buku, internet, jurnal dan koran baik yang dipublikasikan maupun non publikasi.

d. Dokumentasi

Pengumpulan data melalui dokumentasi ini dilakukan pada tahap produksi dalam pembuatan film dokumenter ini. Dokumentasi ini dilakukan secara terjadwal baik pada saat melalukan wawancara dengan narasumber maupun pengambilan gambar yang sebelumnya telah dikomunikasikan.

\section{2) Analisis}

Hasil dari fase pengumpulan data tersebut dianalisa di fase analisis guna mengetahui kebutuhan film, kelebihan, kekurangan maupun target penonton. Hasil yang dilakukan fase analisis ini diantaranya sebagai berikut:

a. Analisis Talent

Adapun talent yang terlibat dalam Film Dokumenter Menepis Julukan Negatif Joged Bumbung yaitu narasumber:

1. Ketut Sumadia sebagai narasumber yang menyampaikan tari joged bumbung dari sekaa wahyu ulangun.

2. Prof. Dr. Nengah Bawa Atmadja, M.A. sebagai narasumber yang menyampaikan perkembangan tari joged bumbung.

b. Analisis Lokasi

Lokasi yang dimaksud merupakan tempat pengambilan gambar untuk film dokumenter ini. Lokasi pengambilan gambar dibagi menjadi dua bagian yaitu indoor (dalam ruangan) dan outdoor (luar ruangan). Lokasi pengambilan gambar disesuaikan dengan film dokumenter ini, meliputi laboratorium sejarah dan teras rumah.

c. Analisis Peralatan

Peralatan yang digunakan dalam pembuatan film dokumenter ini beberapa sudah dimiliki oleh penulis dan untuk beberapa peralatan yang tidak dimiliki nantinya akan didapat melalui menyewa peralatan. Alat-alat yang dibutuhkan sebagai berikut.

1) 1 buah kamera DSLR Canon EOS 700D

2) 1 buah kamera Sony a6300

3) 1 buah lensa EF-S 18-55 mm f/3.5-5.6 IS STM

4) 1 buah tripod

5) 1 buah eksternal microphone 
6) 1 buah laptop dengan spesifikasi processor Intel(R) Core(TM) i3-5005U CPU @2.00GHz 2.00GHz, RAM 4 GB.

d. Analisis Crew

Pada proses pembuatan film dokumenter ini tidak membutuhkan crew dan akan dilakukan oleh penulis. Adapun crew film dalam pembuatan film dokumenter menepis julukan negatif joged bumbung yaitu:

1) Produser : Agus Ari Darma Premana

2) Penulis Skenario : Agus Ari Darma Premana.

3) Sutradara : Agus Ari Darma Premana.

4) Cameraman : Agus Ari Darma Premana.

5) Editor: Agus Ari Darma Premana.

6) Narator: Agus Ari Darma Premana.

e. Analisis SWOT (Strenght, Weakness, Opportunity, Treat)

Analisis SWOT dilakukan untuk mengetahui kekuatan, kelemahan, kesempatan yang bisa didapat, serta ancaman yang mungkin terjadi pada film tersebut. Hal inilah yang akan digunakan sebagai tolak ukur, antara SWOT pada Film Dokumenter Menepis Julukan Negatif Joged Bumbung. Berikut analisisnya:

Tabel 1. Analisis SWOT

\begin{tabular}{|c|c|}
\hline SWOT & $\begin{array}{l}\text { Film Dokumenter Menepis Pandangan Negatif Joged } \\
\text { Bumbung }\end{array}$ \\
\hline Strength & $\begin{array}{l}\text { 1. Tari joged bumbung terdaftar sebagai warisan } \\
\text { budaya tak benda oleh UNESCO. } \\
\text { Mengangkat sejarah dan perkembangan tari } \\
\text { joged bumbung. }\end{array}$ \\
\hline Weakness & $\begin{array}{l}\text { 1. Kekurangan personil. } \\
\text { 2. Keterbatasan alat dalam proses pembuatan } \\
\text { film. } \\
\text { 3. Ilmu broadcast masih sebatas belajar, belum } \\
\text { memenuhi standar profesional produser. } \\
\text { 4. Menentukan jadwal pengambilan gambar } \\
\text { untuk momen pertunjukkan tari joged } \\
\text { bumbung sulit untuk dilakukan karena } \\
\text { pertunjukan bisa dilakukan jika ada yang } \\
\text { memanggil untuk pentas. }\end{array}$ \\
\hline Opportunity & $\begin{array}{l}\text { 1. } \begin{array}{l}\text { Memberikan informasi mengenai } \\
\text { perkembangan tari joged bumbung dan } \\
\text { meluruskan kontroversi mengenai tari joged } \\
\text { bumbung. }\end{array} \\
\text { 2. } \\
\text { Dapat digunakan sebagai sarana sosialisasi } \\
\text { mengenai kesenian tari joged bumbung baik } \\
\text { perorangan, organisasi kesenian sekaa joged } \\
\text { bumbung maupun masyarakat luas. }\end{array}$ \\
\hline Threat & $\begin{array}{l}\text { Adanya film dokumenter sejenis yang lebih } \\
\text { menarik. }\end{array}$ \\
\hline
\end{tabular}

\section{f. Analisis STP (Segmentating, Targeting,} Positioning)

Analisis STP dilakukan untuk penetapan target audiens sebagai ketentuan penyebaran film ke
Volume 8, Nomor 2, Tahun 2019 masyarakat luas. Analisis STP terdiri dari beberapa kriteria berupa pemilahan (segmentating), tujuan/target (targeting) dan penempatan (positioning). Berikut analisisnya :

Tabel 2. Analisis STP

\begin{tabular}{|l|l|l|}
\hline STP & $\begin{array}{l}\text { Film Dokumenter Menepis Pandangan Negatif } \\
\text { Joged Bumbung }\end{array}$ \\
\hline Segmentating & Geografis & $\begin{array}{l}\text { Ditujukkan untuk semua wilayah } \\
\text { yang ada di Indonesia. }\end{array}$ \\
\cline { 2 - 3 } & Demografis & $\begin{array}{l}\text { Film ini bisa ditonton oleh kaum } \\
\text { laki-laki maupun perempuan dari } \\
\text { usia 18 tahun keatas dengan } \\
\text { segala jenis pekerjaan. }\end{array}$ \\
\cline { 2 - 3 } & $\begin{array}{l}\text { Psikografis } \\
\text { Targeting }\end{array}$ & $\begin{array}{l}\text { Dapat disaksikan oleh segala } \\
\text { lapisan sosial. }\end{array}$ \\
& $\begin{array}{l}\text { Target utama penyebaran film dokumenter ini } \\
\text { adalah masyarakat luas, sekaa joged bumbung, } \\
\text { badan/organisasi/komunitas yang memiliki } \\
\text { tujuan untuk melestarikan kesenian Bali seperti } \\
\text { himpunan buteleng, dinas } \\
\text { kebudayaan kabupaten buleleng. }\end{array}$ \\
\hline Positioning & $\begin{array}{l}\text { Sebagai media publikasi film dokumenter ini } \\
\text { akan didistribusikan kepada setiap kalangan. } \\
\text { Dengan mengharapkan kepedulian sosial antar } \\
\text { seksama terkait dengan masalah kontroversi tari } \\
\text { joged bumbung saat ini. }\end{array}$ \\
\hline
\end{tabular}

3. Hasil Tahap 2 (Ide, Sinopsis, Skenario, Storyboard)

Pada tahap 2 terdapat fase pra produksi. Pada tahap ini ide atau topik direalisasikan dalam bentuk ide cerita, sinopsis, skenario, dan storyboard. Hasil dari fase pra produksi dijelaskan sebagai berikut.

1) Ide/Konsep Film

Ide cerita atau konsep cerita dari pembuatan film dokumenter menepis julukan negatif joged bumbung ini adalah berdasarkan fakta yang didapat melalui informasiinformasi publikasi dan non publikasi. Dari informasi tersebut dirangkum bahwa kesenian tari joged bumbung saat ini kebanyakan tidak mementingkan kelestarian seni tari joged bumbung yang seharusnya, melainkan menambahkan inovasi-inovasi yang membuat kesenian ini memiliki julukan-julukan negatif dikarenakan gerakangerakan tarian ini mengandung pornografi dengan banyaknya peredaran videonya di dunia maya. Pada film dokumenter menepis julukan negatif joged bumbung ini akan diceritakan tentang perkembangan kesenian joged bumbung dan meluruskan kontroversi mengenai tarian ini dengan tujuan melestarikan kesenian joged bumbung sehingga masyarakat lebih mengenal tari joged bumbung 


\section{ISSN \\ Kumpulan Artikel Mahasiswa Pendidikan Teknik Informatika}

(KARMAPATI)

Volume 8, Nomor 2, Tahun 2019

dan sadar akan eksistensi kesenian berasal dari hal yang positif.

\section{2) Sinopsis}

Adapun sinopsis dari film dokumenter Menepis Julukan Negatif Joged Bumbung sebagai berikut.

Film ini akan dimulai dari perkenalan kesenian joged bumbung yang sudah sangat terkenal di seluruh wilayah Bali dan sejarahnya. Perkembangan kesenian ini sangat pesat dan mulai banyak bermunculan sekaa joged bumbung di berbagai daerah di Bali. Selanjutnya, semakin banyaknya sekaa joged bumbung menjadikan sebuah tantangan dan berkompetisi untuk bisa mendapatkan konsumen sehingga setiap sekaa mencari ide lain untuk bisa mendapat lebih banyak konsumen dengan gerakangerakan erotis yang ditarikan oleh penari saat pementasan. Dari keadaan inilah timbul kontroversi dimasyarakat dan banyak menimbulkan pemberian julukan yang negatif terhadap kesenian ini.

Masuk pada bagian inti dari film ini adalah dijelaskan mengenai tari joged bumbung yang menggunakan gerakan erotis saat pertunjukan. Selain itu juga akan ada penjelasan mengenai dampak dari beredarnya video. Pada bagian akhir dari film ini menampilkan upaya yang sudah dilakukan pemerintah dengan menggelar pertunjukan di Pesta Kesenian Bali setiap tahun serta solusi dari narasumber terhadap perkembangan dan kelestarian tari joged bumbung untuk kedepannya.

\section{3) Skenario}

Sebelum masuk ke storyboard dibuatlah terlebih dahulu skenario yang berdasarkan pada sinopsis diatas. Skenario dibuat dengan tujuan agar suatu peristiwa terjadi seusuai dengan yang diinginkan.

4) Storyboard

Berdasarkan kronologi yang telah dibangun pada sinopsis dan skenario dibuatlah storyboard sebagai langkah awal alur cerita. Storyboard yang dibangun berupa garis besar tiap prosesi yang ditampilkan dalam film, dalam hal ini berarti rekaman jalannya tiap peristiwa bisa berbeda dengan yang tergambarkan dalam storyboard.

4. Hasil Evaluasi 1

Pada tahap evaluasi 1 ini bertujuan untuk memastikan semua kegiatan yang dilakukan pada proses pra produksi telah terlaksana dengan pemeriksaan checklist.

Tahapan checklist dilakukan oleh peneliti sendiri dengan menulis sesuai hal-hal yang telah dilakukan. Hasil tahapan checklist dapat dilihat pada Tabel 3
Tabel 3. Instrumen checklist

\begin{tabular}{|c|l|c|}
\hline No & \multicolumn{1}{|c|}{ Nama Kegiatan } & Hasil Evaluasi \\
\hline 1 & Perancangan Ide Cerita & Sesuai \\
\hline 2 & Perancangan Sinopsis & Sesuai \\
\hline 3 & Perancangan Skenario & Sesuai \\
\hline 4 & $\begin{array}{l}\text { Perancangan } \\
\text { Storyboard }\end{array}$ & Sesuai \\
\hline 5 & Penentuan Talent & Sesuai \\
\hline 6 & Penentuan Lokasi & Sesuai \\
\hline 7 & Penentuan Peralatan & Sesuai \\
\hline 8 & Penentuan Crew & Sesuai \\
\hline
\end{tabular}

5. Hasil Tahap 3 (Produksi \& Pasca Produksi)

Pada tahap ini terdiri dari fase produksi dan pasca produksi.

Berikut hasil dari fase-fase tersebut.

1) Produksi

Hasil pengembilan gambar ini ada beberapa hal yang mungkin berbeda dengan yang ada di storyboard di karenakan storyboard merupakan sebuah perencanaan sedangkan dalam pengambilan gambar sendiri penulis menemukan informasi-informasi baru yang ditemukan di lapangan, namun secara keseluruhan dari segi alur cerita penulis tetap berpatokan pada skenario dan storyboard. Hasil tahapan produksi dapat dilihat pada gambar berikut.

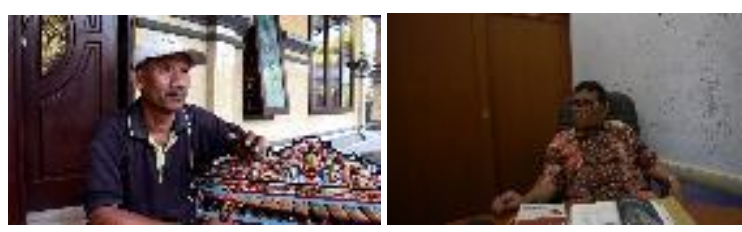

Gambar 3. Pengambilan Gambar Narasumber

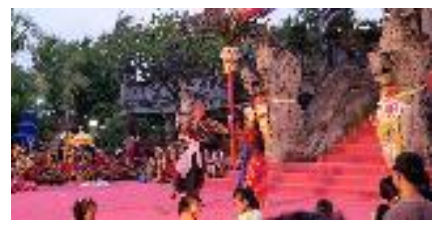

Gambar 4. Pengambilan Gambar Tari Joged Bumbung

\section{2) Pasca Produksi}

Pada fase pasca produksi dalam pembuatan Film Dokumenter Menepis Julukan Negatif Joged Bumbung melalui beberapa tahapan yaitu tahap editing video, editing audio, mixing dan rendering. Adapun hasil dari tahapan tersebut dijabarkan sebagai berikut: 


\section{ISSN \\ Kumpulan Artikel Mahasiswa Pendidikan Teknik Informatika}

a) Editing

Pada tahap editing dilakukan 2 proses yaitu, video editing dan juga sound editing. Proses editing video dapat dilihat pada Gambar 5.

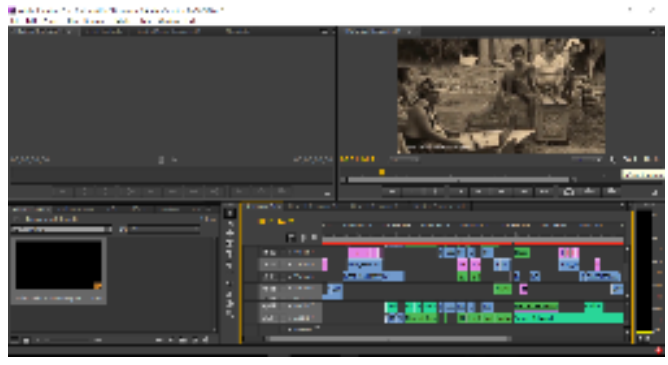

Gambar 5. Proses Editing Video

Pada tahap ini juga dilakukan sound editing. Proses sound editing dapat dilihat pada gambar 6 .

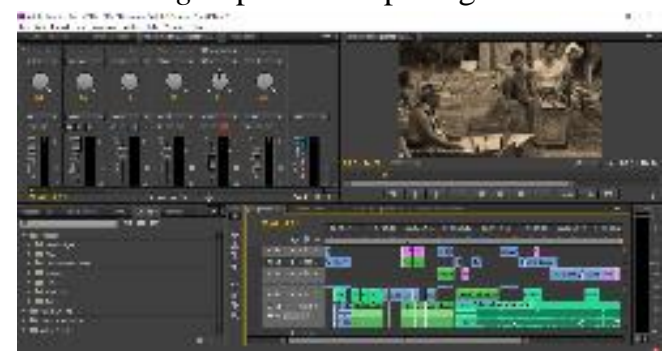

Gambar 6. Sound Recording

\section{b) Mixing}

Tahap mixing ini berfungsi untuk menggabungkan video dan musik latar yang telah diedit sebelumnya. Proses mixing dapat dilihat pada Gambar 7.

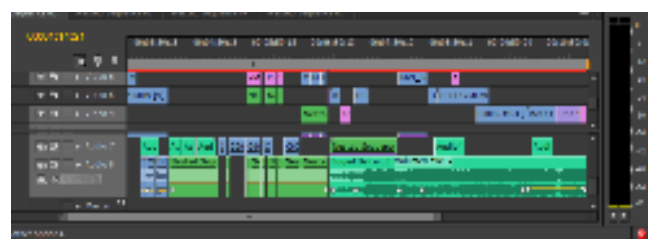

Gambar 7. Proses mixing

c) Rendering

Proses rendering film dokumenter ini dilakukan setelah proses mixing selesai. Proses rendering pada Adobe Premiere Pro CS6 terdapat pada menu fileexport-media. Pada proses rendering, file diubah sesuai format yang telah ditentukan sebelumnya. File yang telah selesai di-render, ditempatkan sesuai dengan direktori tempat meletakkan file tersebut. Proses rendering dapat dilihat pada Gambar 8.
Volume 8, Nomor 2, Tahun 2019

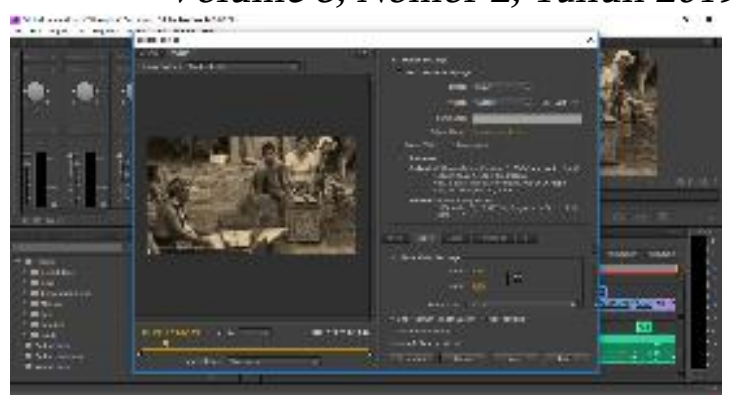

Gambar 8. Proses rendering

6. Hasil Evaluasi 2

Tahap Evaluasi yang ke dua ini merupakan tahap pengujian terhadap film dokumenter yang telah dibuat. Pengujian dilakukan terhadap beberapa ahli yaitu :

1) Uji Ahli Isi

Uji ahli isi telah dilakukan dengan cara mencentang jawaban yang menurut para ahli sesuai. Hasil rekapitulasi diketahui bahwa informasi yang terkandung di dalam film dokumenter sudah jelas dan memperoleh persentase sebesar $85 \%$. Nilai tersebut masuk dalam kategori sangat baik berdasarkan persentase yang didapat.

2) Uji Ahli Media

Pengujian ini dilakukan guna mengetahui kelayakan Film Dokumenter Menepis Julukan Negatif Joged Bumbung sebagai media informasi kepada masyarakat. Hasil pengujian tersebut dengan perolehan skor keseluruhan 33 dari 40 total skor, maka persentasenya mendapatkan $78,3 \%$ dan dikonversi kedalam tabel 4 mendapat kualifikasi sangat baik. Jadi proses dapat dilanjutkan ke tahap berikutnya tanpa revisi.

Tabel 4. Keterangan Tingkat Pencapaian

\begin{tabular}{|c|c|c|}
\hline Tingkat Pencapaian (\%) & Kualifikasi & Keterangan \\
\hline $90-100$ & Sangat Baik & Tidak perlu revisi \\
\hline $75-89$ & Baik & Tidak perlu revisi \\
\hline $65-74$ & Cukup & Revisi \\
\hline $55-64$ & Kurang & Revisi \\
\hline $0-54$ & Sangat Kurang & Revisi \\
\hline
\end{tabular}

7. Hasil Tahap 4

Tahap ini merupakan tahap mastering Film Dokumenter Menepis Julukan Negatif Joged Bumbung. Di mana pada tahap ini diawali dengan proses burning ke dalam bentuk DVD. Dapat dilihat pada gambar di bawah : 


\section{ISSN \\ Kumpulan Artikel Mahasiswa Pendidikan Teknik Informatika}

(KARMAPATI)

tahap pengumpulan data, dilakukan pencarian informasi baik melalui observasi, wawancara, studi pustaka dan dokumentasi. Setelah semua informasi terkumpul, data yang didapat kemudian akan dianalisis. Dalam analisis ini dilakukan analisis kebutuhan film, analisi SWOT dan analisis STP.

Pada tahap 2 dilakukan tahapan pra produksi yang meliputi penentuan ide cerita, sinopsis, skenario dan storyboard. Ide cerita diperoleh dari wawancara terhadap narasumber yang sudah ditentukan. Selanjutnya pembuatan sinopsis yang dibuat berdasarkan ide cerita yang dibuat sebelumnya. Setelah pembuatan ide cerita dilanjutkan dengan pembuatan skenario dan storyboard sebagai acuan dalam proses produksi. Selanjutnya dilakukan evaluasi 1 untuk menguji tahap 1 dan tahap 2.

Tahap 3 adalah tahapan produksi dan pasca produksi. Pada tahapan produksi dilakukan proses pengambilan gambar (shooting) di lokasi-lokasi yang telah ditentukan. Setelah proses pengambilan gambar selesai kemudian dilakukan tahapan pasca produksi film dokumenter. Di mana dalam tahapan ini terdiri dari proses editing, mixing, dan rendering. Setelah pada tahap 3 semua sudah selesai, maka dilakukan evaluasi yang kedua yaitu melakukan uji ahli isi dan uji ahli media. Uji ahli isi dan uji ahli media dilakukan oleh orang-orang yang sudah berkompeten di bidangnya masing-masing.

Setelah dilakukannya uji ahli isi, diperoleh hasil pengujian menggunakan angket dengan persentase rata-rata penilaian yang diperoleh $85 \%$. Berarti bila dikonversikan ke dalam tabel konversi, berada pada kualifikasi baik. Hal ini berarti isi cerita atau informasi yang disampaikan pada film ini sesuai tidak perlu direvisi dan menunjukan bahwa isi informasi di dalam. Sedangkan untuk uji ahli media menggunakan instrumen angket dengan cara mencentang jawaban yang dianggap sesuai, diperoleh hasil rata-rata persentase penilaian yang didapat yaitu sebesar 78,3\% masuk dalam kategori baik. Namun terdapat saran dari penguji ahli media yaitu dimensi tampilan perlu di perbaiki

Pada tahap 4 dilakukan proses mastering file yang sudah dirender, kemudian dikemas dalam bentuk DVD dan dapat dipublikasikan. Dilanjutkan ke tahap outcome yang merupakan tahap terakhir pada pembuatan film ini. Tahapan outcome ini adalah mempublikasian Film Dokumenter Menepis Julukan Negatif Joged Bumbung yang telah dibuat dan disosialisasikan dengan media poster.

Uji respon penonton adalah pengujian untuk mengetahui bagaimana respon penonton setelah menonton film dokumenter ini. Pada uji respon penonton film dokumenter ini peneliti melakukan pengujian terhadap 30 orang responden yang
Volume 8, Nomor 2, Tahun 2019

merupakan masyarakat umum dengan rentangan usia 18 tahun keatas. Hasil dari keseluruhan uji respon penonton diperoleh presentase sebanyak $81,6 \%$ yang dikonversikan ke dalam tabel konversi menyatakan pencapaian baik.

Salah satu penelitian terkait dengan film dokumenter ini adalah penelitian dari Yudiana Sucitra (2017) mengenai "Pengembangan Film Dokumenter Tradisi Dewa Mesraman Di Pura Panti Timrah Klungkung" yang menggunakan model cyclic strategy dalam pembuatan filmnya dan menjadi sebuah media penyalur infomasi serta sosialisasi mengenai pelestarian budaya bali.

Pembuatan Film Dokumenter Menepis Julukan Negatif Joged Bumbung tidak lepas dari berbagai kendala. Adapun kendala-kendala yang dihadapi salah satunya yaitu menentukkan jadwal untuk shooting wawancara dengan narasumber, namun dapat teratasi dengan menjalin komunikasi dan koordinasi yang baik.

Beberapa kendala juga dialami saat pengambilan gambar, seperti banyaknya suara noise yang masuk karena kebanyakan pengambilan gambar dilakukan di luar ruangan dan juga keterbatasan alat. Namun dengan memanfaatkan software Adobe Premiere Pro CS6 untuk mengurangi noise suara, kendala tersebut teratasi.

Film dokumenter ini dapat menyampaikan realitas yang ada di lapangan serta dibuat dengan manfaat untuk memberikan informasi bagi penonton mengenai tari joged bumbung.

\section{SIMPULAN DAN SARAN}

Berdasarkan hasil penelitian dan pembahasan Film Dokumenter Menepis Julukan Negatif Joged Bumbung, maka penulis dapat menarik kesimpulan sebagai berikut.

1. Perancangan Film Dokumenter Menepis Julukan Negatif Joged Bumbung telah berhasil dilaksanakan menggunakan model cyclic strategy dengan menggunakan tahapan produksi film, yaitu pra produksi, produksi, pasca produksi, dan pengujian. Film Dokumenter Menepis Julukan Negatif Joged Bumbung telah berhasil diimplementasikan sesuai dengan rancangan yang telah dibuat sebelumnya. Film dokumenter ini menggunakan aplikasi Adobe Premiere Pro CS6 dalam proses video editing serta Adobe Photoshop CS6 untuk pembuatan desain keperluan film dokumenter.

2. Film Dokumenter Menepis Julukan Negatif Joged Bumbung memperoleh persentase sebesar $85 \%$ dari uji ahli isi dan juga 78,3\% dari uji ahli media yang dikonversikan ke dalam Tabel 3.5. menyatakan "Baik". Berdasarkan dari hasil uji respon penonton dengan menyebarkan angket uji respon penonton menunjukkan persentase yang diperoleh 
adalah 81,6\% yang dikonversikan ke dalam Tabel 3.5. [9] menyatakan "Baik".

Saran yang dapat penulis berikan berdasarkan hasil dari penelitian dan pembahasan dari Film Dokumenter Menepis Julukan Negatif Joged Bumbung antara lain sebagai berikut :

1. Peneliti berikutnya dapat mengembangkan penelitian yang lebih spesifik terkait joged bumbung porno yang sangat meresahkan. Dikarenakan dalam proses penelitian ini peneliti belum bisa medapatkan informasi mendalam dari seorang pelaku penari joged bumbung porno.

2. Pengujian yang dilakukan disarankan untuk melakukan uji ahli media yang bertujuan untuk mencegah kesalahan kesalahan yang terjadi dalam proses shooting dan recording.

3. Peneliti berikutnya disarankan agar mempersiapkan dari sisi teknis sebelum melakukan pengambilan gambar, seperti teknis dalam menentukan sudut pengambilan gambar dengan kamera agak tidak monoton.

\section{REFRENSI}

[1] Atmadja, N. B. (2010). Komodifijasi Tubuh Perempuan Joged "Ngebor" Bali. Denpasar: Pustaka Larasan.

[2] Bandem, M. (1996). Etnologi Tari Bali. Denpasar: Pustaka Budaya.

[3] BPNBBali. (2015, Mei 28). Joged Bumbung: Dari Sederhana Menjadi Fenomenal. Retrieved March 31, 2016, from :

http://kebudayaan.kemdikbud.go.id/bpnbBali/2015/0 5/28/Joged-bumbung-dari-sederhana-menjadifenomenal/

[4] Ciptadi, A., \& Tumimomor, A. Y. (2013). Perancangan Film Dokumenter Pasar Terapung Muara Kuin di Banjarmasin, Kalimantan Selatan.

[5] Manggala, Y. (2015, Desember 3). Sembilan Tari Bali Diusulkan Masuk Kurikulum. Retrieved March 28, 2016, from :

http://www.republika.co.id/berita/nasional/daerah/15/ 12/03/nys644284- sembilan-tari-Bali-diusulkanmasuk-kurikulum

[6] Narayana, I. A. (2017). Film Dokumenter Tok Lait Kancing : Sebuah Warisan Karakter Budaya Bangsa. Kumpulan Artikel Mahasiswa Jurusan Teknik Informatika (KAMAPATI) ISSN 2252-9063 Volume 6, Nomor 1, 2017.

[7] Pratista, H. (2008). Memahami Film. Yogyakarta: Homerian Pustaka.

[8] Sarwono, J., \& Lubis, H. (2007). Metode Riset untuk Desain Komunikasi Visual. Yogyakarta: ANDI.
Winyana, I. N. (2015). Seni Tradisi Joged Bumbung Diantara Tontonan Estetika Dan Etika. Vidya Samhita. Yudiana Sucitra, I. H. (2017). Pengembangan Film Dokumenter Tradisi Dewa Mesraman Di Pura Panti Timrah Klungkung. Kumpulan Artikel Mahasiswa Pendidikan Teknik Informatika (KARMAPATI) ISSN 2252-9063 Volume 6, Nomor 1, 2017. 